\title{
Use of Game Images to Improve Results and Learning Activities of The Beautiful Materials of The Equality of Class IV Students in SD Kartika XIX-4 Cimahi
}

\author{
Galih Dani Septian Rahayu, Euis Eti Rohaeti, Asep Samsudin, Dinno Mulyono, Susilawati \\ \{ galih040990@ikipsiliwangi.ac.id¹, e2rht@ikipsiliwangi.ac.id², asepsam234@ikipsiliwangi.ac.id³, \\ dinno@ikipsiliwangi.ac.id $\left.{ }^{4}\right\}$ \\ PGSD, IKIP Siliwangi, Cimahi, Indonesia ${ }^{1,3}$, Pendidikan Matematika, IKIP Siliwangi, Cimahi, \\ Indonesia $^{2}$, Pendidikan Masyarakat, IKIP Siliwangi, Cimahi, Indonesia ${ }^{4}$, Teacher of SD Kartika XIX-4, \\ Cimahi, Indonesia ${ }^{5}$
}

\begin{abstract}
Active and creative attitudes are the main capital for elementary school students in getting optimal learning outcomes, because it is used in understanding the material about the beauty of diversity using a thematic approach. As many as $80 \%$ of students in grade IV SD Kartika XIX-4 need a variety of learning to avoid boredom in learning, especially because of thematic material that makes students try harder to understand each learning context. The theory used is the concept of games, the concept of strategies and methods of learning and classroom action research. The method used is classroom action research consisting of 2 cycles with stages of planning, action, observation and reflection. Research Subjects were fourth grade students of SD Kartika XIX-4 totaling 36 students. The results obtained are there is an increase in student learning outcomes by using picture games in the learning process. With the final conclusions of this study is a picture game can be used to improve the results and learning activities in the material Beautifulness of togetherness for grade IV students of SD Kartika XIX-4, Cimahi.
\end{abstract}

Keywords: drawing games, results and student learning activities.

\section{Introduction}

Basic education is one of the main education processes in building an understanding of social life, especially in terms of the life of the nation and state in various contexts within it. This is because after family education, the next education is education in elementary school. In addition, with the development carried out thematically, it is expected that students can understand the use of science in a more practical field, including its application in the midst of everyday life.

Learning in elementary schools that use a thematic approach provides opportunities for students to understand the context of learning in a comprehensive and interdisciplinary manner, but it challenges the ability of students to use theory in a more concrete context, so that teachers are also required to provide more practical examples in accordance with the conditions. current community life. Teachers are required to be able to deal with various learning difficulties of students by using learning strategies that are more applicable and in accordance with the task of developing elementary school students. Teachers in this case must 
be better able to provide motivation in building learning independence as well as the ability to solve problems that exist in the learning process itself.

The difficulty in motivating students or giving rise to students' liking towards the learning process is also felt by the Teacher of Class IV SD Kartika XIX-4. This is motivated by the difficulty of the material, the condition of the school environment, the mental condition and the readiness of students in following the learning process carried out in the classroom. Therefore, teachers are required to be able to develop learning methods that are more varied according to the needs of students, so that students can follow the learning and achieve the learning objectives as expected.

Therefore, in the end a different learning approach was carried out, including using picture games in explaining and giving training to students. So that students not only see images in a passive form, but in more active conditions. This is to facilitate students who have kinesthetic potential compared to visual and auditory, while for students who have auditory potential will receive an explanation from their peers who are involved in the process of group learning and not only learn independently.

\section{Theoretical Basis}

\subsection{Game Concept}

Games are one approach to learning. In the opinion of Kimpraswil (in As'adi Muhammad, 2009: 26) suggests that the game is an attempt at self-effort (mind and physical processing) that is very beneficial for improving and developing motivation, performance, and achievement in carrying out the duties and interests of the organization better. The game provides an opportunity for students to further explore their personal abilities, especially training in concentration and skills in choosing the pattern of movement that will be carried out.

Another case with [1] defines the game as an activity that helps children achieve complete development, both physical, intellectual, social, moral, and emotional. Game transitions in learning require concentration and the ability to process physically and continuously, so as to provide opportunities for students to better understand the concept of learning as a whole and be more active in the learning process.

From the opinions of some experts it can be concluded that the definition of the game is an activity carried out by several children to seek pleasure that can shape the child's personality process and help children achieve physical, intellectual, social, moral and emotional development. With this ability, it is expected to develop various programs related to improving students' skills in physical processing, understanding and various social skills in the continuous learning process.

The characteristics of playing learning methods are:

1. Students in the group are given the opportunity to complete learning material according to the basic competencies that will be achieved.

2. Groups are formed with different student abilities, both high, medium and low. if possible group members come from different races, cultures, tribes and pay attention to gender equality.

3. Awards emphasize more on groups than each individual. 
Play learning also has several disadvantages and advantages, including the following:

\section{Advantages of the Game Method}

1. Train children to dramatize things and exercise courage

2. This method will attract children's attention so that the classroom atmosphere comes alive.

3. Children can live an event so that it is easy to draw conclusions based on their own appreciation.

4. Children are trained to organize their thoughts regularly.

\section{Lack of Game Methods}

1. Not all topics can be presented through the game.

2. Requires a lot of time

3. Determination of losing win and pay-pay can have negative consequences.

4. There may also be a fight.

5. Disturb the peace of learning in other classes.

In some learning processes, learning methods through games also have several important principles, including the following:

1. The game developed should be a game that is directly related to the daily context of students.

2. The game is applied to stimulate thinking power, access information and create new meanings.

3. The game that is being played must be fun and exciting for students.

4. The game is carried out on the basis of the freedom to establish cooperation with other students.

5. Games should be challenging and contain elements of competition that allow learners to be more motivated through the process

Some characteristics of learning methods through games are as follows:

1. Enabling more students

2. Many use media / props, both original and other media.

3. Requires teacher creativity

4. Requires a long time

5. Can motivate students in learning

6. Can create students 'understanding and students' memory will not be easily lost.

\subsection{Concept of Strategies and Learning Methods}

The implementation of active, innovative, creative, effective and fun learning that will be carried out both inside and outside the classroom requires careful preparation by all subjects. The intended preparation is the Learning Implementation Plan (RPP) is a scenario in learning. In the preparation of the RPP an educator needs to pay attention to what types of approaches and methods will be chosen and used in Teaching and Learning Activities (KBM). The choice of an approach and method must certainly be adapted to the learning objectives and the nature of the material that will become learning. In essence, no subject matter has ever been presented using only one method. Learning by using many methods will support the achievement of more meaningful learning goals [2]. This is done so that the learning objectives that have been prepared can be achieved well. 
The choice of learning methods and strategies must be tailored to the situation and conditions and the needs of students. This clearly must be mastered by the teacher. In short, in Teaching and Learning Activities (KBM) teachers must be able to master various methods that are most appropriate in accordance with the subject matter taught.

Mastery of methods, tools / media and learning techniques must be used appropriately and thoroughly in classroom learning programs. So basically the learning process must be varied, the method used is not monotonous, so that the child's potential can be developed optimally.

These demands can be carried out well if the teacher in question has professional skills, especially having the motivation to teach and technical instructional abilities, so that the teacher is able to master class conditions and create a conducive learning climate and have a variety in a better learning approach.

Learning strategies need to be understood thoroughly, [3] suggests that learning strategies are action plans (series of activities) including the use of methods and the use of various resources in learning to achieve certain goals.

Learning strategies also use several techniques that can be used, including expository, inquiry and social inquiry. But in the learning process used in classroom action research in Class IV SD Kartika XIX-4, Cimahi uses expository and inquiry learning strategies. This is because the teacher is given the opportunity to explain a number of theories first, then the students are given access to be able to carry out some picture play activities in theme 2 , subtheme 4, Beautiful diversity.

Learning is often identified with the teaching-learning process, although in it it can involve various processes to build students' experiences in each learning process. The process in the sense here is the interaction of all the components or elements contained in the learning process, where the components are one with the other (interindependent), in a bond to achieve the goal. What is meant by components or elements of teaching and learning include instructional objectives, which are to be achieved in learning, teaching methods, teaching aids, and evaluation as a measure of whether or not learning objectives are achieved.

\section{Research Methods}

The research method used in this study is classroom action research (CAR). Classroom action research according to [4] is research conducted with the aim of improving the quality of classroom learning practices. CAR has a very important and strategic role to improve the quality of learning if implemented properly and correctly. Research conducted using collaborative research. According to Suwarsih Madya [5] states that classroom action research is participatory and collaborative because there is a shared concern for classroom learning situations that need to be improved.

This research was carried out on the fourth grade students of SD Kartika XIX-4 Cimahi, West Java. This research was conducted in odd semester. This selection is adjusted to the theme and time specified for the learning process about the beauty of togetherness. This research was carried out in 3 cycles. The subjects in this study were 36 students of grade IV SD Kartika XIX-4, Cimahi. The main data sources in this study were fourth grade students of SD Kartika XIX-IV Cimahi and Class Teachers, namely Ms. Susilawati, S.Pd. Elementary school. 


\section{Results And Discussion}

\subsection{Results}

The implementation of the theme learning The beauty of togetherness in the initial cycle shows conditions that are less supportive, especially in terms of student participation in learning and the achievement of learning objectives related to the theme of the beauty of diversity. This is a challenge for class teachers, in this case Ibu Susilawati, S.Pd. Elementary school.

In the previous learning process, the teacher used the book as a worksheet only, and several other learning media, however the learning process felt still needed to be improved, because there were some shortcomings, including the final value gaining gap between students who have special potential with some other students who have the potential in other fields. This is an obstacle in achieving minimum completeness criteria. This encourages teachers to start considering the use of other learning media to build a more conducive learning climate in the classroom.

Below are the learning outcomes of students with learning conditions as described above:

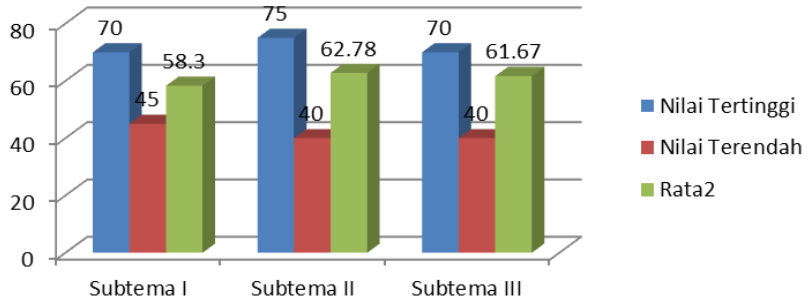

Fig 1. Student Learning Outcomes in Class IV SD Kartika XIX-4 Pre-Cycle

From the figure 1 above, it is known that the value for pre-cycle is still lacking compared to the conditions that must be achieved to achieve the minimum completeness criteria, while the average for minimum completeness criteria is at number 70 . This shows that the learning process is running, but requires greater encouragement, especially in sub-themes I and Subtema II. In sub-theme III, even though it is close to 70, it has not been exceeded in full, so it requires strengthening so that students can get better grades.

Different results are shown in cycle I, where most students show a fairly good development, as shown in figure 2 below:

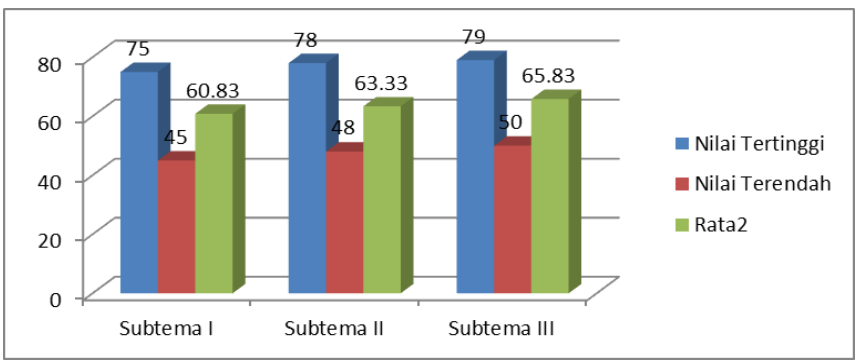

Fig 2. Student Learning Outcomes in Class IV SD Kartika XIX-4 Cycle I 
From the figure 1 above, it is known that the value for cycle I is still lacking compared to the conditions that must be achieved to achieve minimum completeness criteria, while the average for minimum completeness criteria is at number 70. This shows that the learning process has run better than the conditions pre-cycle, but requires greater encouragement, especially in sub-themes I and Subtema II, this is because the value achieved still has not touched the number 70 according to the minimum completeness criteria. In sub-theme III, even though it is close to 70 , it has not been exceeded in full, so it requires strengthening so that students can get better grades. But for cycle one, it shows a pretty good improvement compared to pre-cycle.

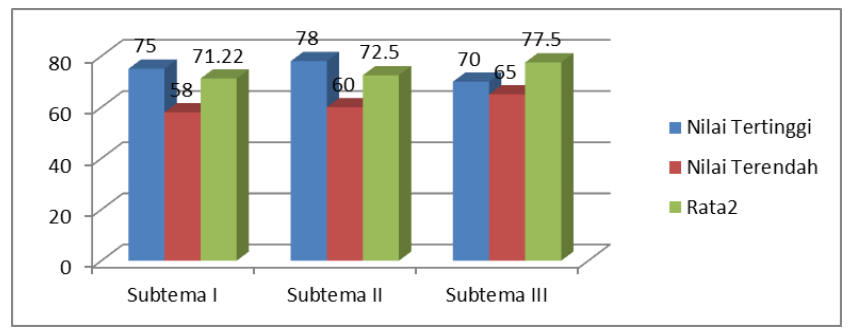

Fig 3. Student Learning Outcomes in Class IV SD Kartika XIX-4 Cycle I

From the picture above it is obtained for the cycle II, has experienced a significant development compared to the conditions at pre-cycle. The value obtained has reached the minimum completeness criteria, especially for the average minimum completeness criteria which is at number 70 . This shows that the learning process is in cycle I.

\subsection{Discussion}

In the pre-cycle activities it was found that the acquisition of scores for the theme The beauty of togetherness in the fourth grade students of SD Kartika XIX-4 still got low scores, this was due to various obstacles that occur in the learning process, such as different learning climate, mental condition and student learning readiness, the school environment and very likely different children's potential will greatly affect the learning outcomes themselves. However, in the first cycle, the acquisition of student scores shows a fairly good increase, this indicates that the learning approach through drawing games provides a new situation, which encourages students to participate more in the learning process. In the second cycle, the results of students' scores showed significant changes, this added value and showed that with the right learning method, students were able to develop better activities and get the right focus for each learning material in the classroom. The increase in the second cycle is also still possible because teachers try to provide variations in the use of media and learning strategies in addition to providing motivation at every opportunity. This is consistent with the opinion of another resercher that motivation is the driving force, driving and reinforcing behavior.

With the description above shows that the use of drawing games in the learning process carried out through the right steps, can increase student activity and learning outcomes. This can be proven by an increase in activity, student learning outcomes and the percentage of categories of student learning outcomes that increase in each cycle. [6] who states that language games can train students' skills and make students more active. By playing, can be obtained a joy or satisfaction, behind satisfaction or excitement actually students get a number of skills. Because it can solve the challenges in the game. 


\section{Conclusion}

Based on the results of the research and discussion, it was found that the use of drawing games can be used to improve the results and learning activities of the beautiful class 4 students of SD Kartika XIX-4 Cimahi. This is indicated by an increase in student learning outcomes, after using the learning method. However, there are several other factors, including the use of more varied learning media, as well as teacher support factors in the form of motivating students, and of course creating a learning climate that supports various types of student learning, will greatly affect student learning outcomes.

Acknowledgment. Thank you to the Directorate of Learning and Student Affairs, Ministry of Research and Technology for the Lecturer to School Assignment Program (PDS) given to IKIP SIliwangi.

\section{References}

[1] J. Freeman and M. Utami, Cerdas Cemerlang. jakarta: PT. Gramedia Pustaka Indonesia., 2001.

[2] N. Rustaman and A. Rustaman, "Peranan Pertanyaan Produktif dalam Pengembangan KPS dan LKS," in Seminar dan Lokakarya Bagi Guru SLTP dan SMU, 2003, pp. 102-120.

[3] W. Sanjaya, Strategi Pembelajaran. jakarta: Kencana Prenada Media Group., 2006.

[4] Kunandar, Langkah Mudah Penelitian Tindakan kelas sebagai Pengembangan Profesi Guru. jakarta: PT. Raja Grafindo Persada, 2008.

[5] J. M. Asmani, Tips Aplikasi PAKEM (Pembelajaran Aktif, Kreatif, Efektif dan Menyenangkan). Yogyakarta: Diva Press, 2014.

[6] Suyanto, Multimedia Alat untuk meningkatkan keunggulan bersaing. jakarta: PT. Elex Media Komputindo, 2013. 